\title{
Influence of Chromium Salts on Increased Lipid Peroxidation and Differential Pattern in Antioxidant Metabolism in Pistia stratiotes $\mathbf{L}$.
}

\author{
RishiKesh Upadhyay* and Sanjib Kumar Panda \\ Plant Biochemistry and Molecular Biology Laboratory; School of Life Sciences; Assam Central University; \\ Silchar-788011; India
}

\begin{abstract}
In this work, the changing effect of different concentrations (0, 0.01, 0.1, 1, 10mM) of hexavalent and trivalent chromium on different biochemical parameters along with antioxidant enzymes was investigated on water lettuce (Pistia stratiotes L.) in order to know the possible involvement of this metal in oxidative injury, besides the activities of antioxidant enzymes leading to biochemical and oxidative aberration induced by elevated concentrations. Both in roots and shoots, $\mathrm{Cr}$ produced a significant increase in enzymic and non-enzymic antioxidants, except in catalase (CAT) activity where a strong accumulation of hydrogen peroxide was indicated, suggesting an imposition of oxidative stress. The observation showed an uptake of chromium by P. stratiotes L. as well as increase in activity of antioxidants, as the concentrations and their duration of treatment increased. The activity of antioxidative enzymes determined the steady-state levels of ROS in the cell. The augmentation of antioxidative defense plays a key role in regulating the oxidative stress. This pointed to the possibility in induction of oxidative stress, with the increasing lipid peroxidation, followed by a differential pattern in antioxidant metabolisms by chromium ions in P. stratiotes L.
\end{abstract}

Key words: Biochemical alterations, Chromium stress, Lipid peroxidation, Oxidative stress, Pistia stratiotes L., Reactive oxygen species.

\section{INTRODUCTION}

In natural environment, trace amounts of heavy metals are essential, but become toxic when their concentration exceeds certain levels. The aquatic plants absorb metals from the air, water and soil. The uptake depends upon the soil $\mathrm{pH}$, drainage status, plant species, chemical form and location. Amongst them, chromium is one of the most widely distributed heavy metals in the earth's crust. It is usually released into the environment through industrial effluents and other human activities (WHO, 1998), besides being important for the organisms such as nutrients, and its deficiency may result in several disorders, leading to the inhibition of growth, thereby inducing the oxidative damage and several biochemical lesions in plant cell (Upadhyay and Panda, 2005). Chromium in +3 oxidative state remains nontoxic; in +6 oxidative state, it is highly toxic, both in soil and aquatic environment. Both forms of $\mathrm{Cr}$ differ in terms of mobility, bioavailability and toxicity (Panda and Choudhury, 2005). $\mathrm{Cr}$ in the plants causes deleterious effects on gas exchange, chlorophyll a fluorescence, photosynthetic pigment contents and alterations in thylakoid

*Author for correspondence: rishik.upadhyay@yahoo.com 
stacking (Paiva et al., 2009). Chromium also involves in the activation as well as regulation of enzymes related to the plant defense system, which has already been reported from diverse groups of plants by Upadhyay and Panda (2004). Studies carried out in different plant species have revealed that $\mathrm{Cr}$ is strongly phytotoxic, and causes growth inhibition and even death, although the mechanisms involved in its toxicity are still not completely understood. The active oxygen species (AOS) cause lipid peroxidation, bringing about membrane injury, protein degradation, enzyme inactivation, pigment bleaching and disruption of DNA strands (Razinger et al., 2007; Panda and Upadhyay, 2008). The detoxifications of these active oxygen species are of prime importance in any defense mechanism. These active oxygen species produced excessively under stressful conditions are removed by the complex nonenzymic (AsA, ascorbate, GSH, glutathione, $\alpha$ tocopherol) and enzymic (CAT, Catalase; GPx, guaiacol peroxidase; SOD, superoxide dismutase; GR, glutathione reductase, etc.) antioxidant systems (Gratão et al., 2005). Modulation in the activities of these enzymic and non-enzymic antioxidant systems may be important in plant's resistance to environmental stress.

Chromium is an important water contaminant with an ability to induce the cellular damages in the plant and animal organisms. It can easily penetrate into the biological membranes and is relatively stable in water over a large $\mathrm{pH}$ range (Fasulo et al., 1992).

In this work, $P$. stratiotes $\mathrm{L}$. was chosen being one of the important components of the natural ecosystem on a food source for fishes and mammals (Arber, 1963; Culley et al., 1981). The study was undertaken to know the possible differential participation as well as effect of chromium on antioxidant status so as to analyze the significance of these antioxidant status in imparting chromium stress tolerance to freshly grown aquatic macrophyte, P.stratiotes $\mathrm{L}$.

\section{MATERIALS AND METHODS}

P.stratiotes L. were collected from the local pond. The collected plants were washed with double distilled water several times besides soaking dry without damaging the tissue. Five plants were transferred to sterile petri plates. Chromium was administered as $\mathrm{Cr}_{2} \mathrm{O}_{3}$ and $\mathrm{K}_{2} \mathrm{Cr}_{2} \mathrm{O}_{7}$ at concentrations ranging from $0-10 \mathrm{mM}$ with three replicates each. Petri plates were incubated under cool and white fluorescent tube lights (Philips 36 $\mathrm{W}$, TLD, India), giving a photon flux density (PFD) of $52 \mu \mathrm{mol} \mathrm{m}^{-2} \mathrm{~s}^{-1}$ for 24 and $48 \mathrm{~h}$ at $25 \pm 2$ ${ }^{\circ} \mathrm{C}$. After the treatments, the roots and shoots of plants were separated out, soaked dry in Whatman No.1 blotting paper and sampled for various biochemical and enzymic investigations.

The level of lipid peroxidation was measured in terms of malondialdehyde (MDA), a product of lipid peroxidation in the samples estimated by thiobarbituric acid (TBA) reaction (Zhang, 1992). Correction of non-specific turbidity was made by subtracting the absorbance value taken at $600 \mathrm{~nm}$ using UV-visible spectrophotometer (Systronics, Gujarat, India). The level of lipid peroxidation was expressed as $\mu$ mol of malondialdehyde (MDA) by using an extinction coefficient $155 \mathrm{mM} \mathrm{cm}^{-1}$. The $\mathrm{H}_{2} \mathrm{O}_{2}$ level was expressed as $\mu$ mol of $\mathrm{H}_{2} \mathrm{O}_{2}$ destroyed $\min ^{-1} \mathrm{~g}$ fr. $\mathrm{wt}^{-1}$ at $25 \pm 2{ }^{\circ} \mathrm{C}$. (Sagisaka, 1976).

The tissues of roots and shoots were homogenized in ice cold $0.1 \mathrm{M}$. Tris - $\mathrm{HCl}$ buffer $(\mathrm{pH} 7.8)$ containing $0.1 \mathrm{mM}$ EDTA. The homogenate was centrifuged at $12000 \mathrm{rpm}$ at $0-4{ }^{\circ} \mathrm{C}$ for $20 \mathrm{~min}$ and the supernatant was used as enzyme extract. CAT activity was estimated as per the method of Chance and Maehly (1955), expressed as $\mu$ mole of oxygen destroyed $\mathrm{min}^{-1} \mathrm{~g}$. fr. $\mathrm{wt}^{-1}$ at $25 \pm 2{ }^{\circ} \mathrm{C}$. GPx activity was measured according to Chance and Maehly (1955). The rate of absorbance at $420 \mathrm{~nm}$ was measured by using UV - visible spectrophotometer (Systronics, India), expressed as units $\mathrm{g}^{-1} \mathrm{FW}$ at $25 \pm 2{ }^{\circ} \mathrm{C}$.

The measurement of SOD activity was assayed as per the method of Giannopolitis and Ries (1977). The reaction was initiated by placing the glass test tubes in between two fluorescent tubes (Philips, 20W). Switching the light on and off, the reaction mixture was illuminated and terminated. The increase in absorbance due to the formation of formazan was read at $560 \mathrm{~nm}$. Under the above conditions, the increase in absorbancy in the absence of enzyme was initially taken $100 \%$ and $50 \%$ as an equivalent to 1 unit of SOD activity. Estimation of GR was done as per the method of 
Smith et al. (1988). Increase in the absorbance at $412 \mathrm{~nm}$ was recorded at $25{ }^{\circ} \mathrm{C}$ over a period of $5 \mathrm{~min}$ spectrophotometrically and the activity was expressed as absorbancy change $\left(\Delta \mathrm{A}_{412}\right)$ per gm fresh mass per sec.

GSH+GSSG contents were determined according to the method of Griffith (1980). Two grams tissue was homogenized in $5 \%(\mathrm{~m} / \mathrm{v})$ sulfosalicylic acid and the homogenate was centrifuged at 10000 $\mathrm{rpm}$ for $10 \mathrm{~min}$. The supernatant $(1 \mathrm{ml})$ was neutralized with $0.5 \mathrm{ml}$ of potassium phosphate buffer (pH 7.5). Total glutathione (GSH+GSSG) content was measured by adding $1 \mathrm{ml}$ neutralized supernatant to a standard solution mixture consisting of $0.5 \mathrm{ml}$ of $0.1 \mathrm{M}$ sodium phosphate buffer ( $\mathrm{pH}$ 7.5) containing $1 \mathrm{ml}$ EDTA, $0.2 \mathrm{ml}$ of 6 $\mathrm{mM} \mathrm{5,5}$ 'dithiobis (2-nitrobenzoic acid), $0.1 \mathrm{ml}$ of $2 \mathrm{mM}$ NADPH and $0.1 \mathrm{ml}$ of $1 \mathrm{U}$ yeast GR TypeIII (Sigma Chemical, St. Louis, USA). The change in the absorbance was measured at $412 \mathrm{~nm}$ and followed at $25 \pm 2{ }^{\circ} \mathrm{C}$ until the absorbance reached 0.5 units. The ascorbate (AsA) extraction and estimation was done by the method of Oser (1979). The reaction mixture contained $2 \mathrm{ml} 2 \%$ Na-molybdate, $2 \mathrm{ml} 0.15 \mathrm{M} \mathrm{H}_{2} \mathrm{SO}_{4}, 1 \mathrm{ml} 1.5 \mathrm{mM}$ $\mathrm{Na} 2 \mathrm{HPO} 4$ and $1 \mathrm{ml}$ root tissue extract. It was mixed and incubated at $60{ }^{\circ} \mathrm{C}$ in water bath for 40 $\mathrm{min}$, then cooled, centrifuged at 3,000 rpm for 10 min and absorbance was measured at $660 \mathrm{~nm}$.

All the observations were done in triplicate, repeated thrice and the data represented mean \pm standard error of mean (SEM). The results were subjected to ANOVA using GLM factorial model for all the parameters. Turkey test was used for comparison between the control and treated plants. The data analyses were carried out using SPSS 7.5. In figures, the values are marked as * (astrick) for the significance level $(\mathrm{P} \leq 0.05)$ as compared to control.

\section{RESULTS AND DISCUSSION}

The effect of different doses with different durations of trivalent and hexavalent chromium showed that increasing $\mathrm{Cr}$ concentrations initiated an increase in the capacity of antioxidative defense system in the plants. Oxidative stress resulted from the increased levels of ROS in cells were exposed to heavy metals $\mathrm{Cr}^{+6}$, prompting the production of $\mathrm{H}_{2} \mathrm{O}_{2}$ and MDA. An increase in $\mathrm{H}_{2} \mathrm{O}_{2}$ contents was observed with the increase in concentration of chromium ions. The $\mathrm{H}_{2} \mathrm{O}_{2}$ content increased maximum by $32 \%$ after $48 \mathrm{~h}$ of $10 \mathrm{mM} \mathrm{Cr}^{+6}$ treatments in comparison to control (Fig. 1A). Hydrogen peroxide is a toxic compound produced as a result of scavenging of superoxide radical, and a higher concentration in injurious to cell/plant, resulting in lipid peroxidation and membrane injury (Gratão et al., 2008; Upadhyay and Panda, 2009). After 48h, the MDA content resulted in increase in the root cells. The content increased by 182 and $140 \%$ in comparison to control at $10 \mathrm{mM}$ $\mathrm{Cr}^{+6}$ in the roots and shoots. (Fig.1B). The $\mathrm{H}_{2} \mathrm{O}_{2}$ levels increased with the increase in concentration level as well as duration of the treatment. $\mathrm{H}_{2} \mathrm{O}_{2}$ acts as a secondary messenger, which is capable of activating various responses in plants (Vranova et al., 2002). Similar results in $\mathrm{H}_{2} \mathrm{O}_{2}$ production rates were also reported in previous investigations (Upadhyay and Panda, 2005). Lipid peroxidation is considered to be an induction of oxidative stress. It was measured in terms of TBARS, chiefly MDA increased with the increase in dose of metal treatment, in the roots and shoots of P.stratiotes L. This could be due to the generation of free radicals that might distort the membrane architecture, which caused an oxidative damage as reported in other higher plants (Sinha et al., 2005; Hou et al., 2007).

The level of non-enzymic antioxidant, AsA and GSH+GSSG, is shown in Figs. 1C and D. As shown in Fig. 1C, the AsA and GSH+GSSG in shoots were higher after $48 \mathrm{~h}$ of $\mathrm{Cr}^{+6}$ treatments. The analysis of AsA contents after $48 \mathrm{~h}$ of $\mathrm{Cr}^{+6}$ treatment showed an increase by 295 and $78 \%$ at $10 \mathrm{mM}$, in root and shoot, respectively. The GSH+GSSG level, on the other hand, was not significantly affected by $\mathrm{Cr}^{+3}$, after 24 or $48 \mathrm{~h}$ of the treatment. But the $48 \mathrm{~h} \mathrm{Cr}^{+6}$ treatment resulted in $168 \%$ increase in GSH+GSSG level at $10 \mathrm{mM}$ concentration (Fig. 1D) in shoot. However, a gradual increase in GSH+GSSG and AsA levels as well, could suggest an induction of oxidative stress (Gallego et al., 1996) as well as its participation in detoxification of ROS (Upadhyay and Panda 2005; Panda and Upadhyay, 2008). The antioxidant enzymes showed variation in their response to $\mathrm{Cr}^{+3}$ and $\mathrm{Cr}^{+6}$ (Figs. 2A and D). In order to repair the damage initiated by the ROS, plants have evolved complex antioxidant defense system that included both enzymic and non-enzymic antioxidants. ROS steady-state levels depend on the balance between 
ROS synthesis and their destruction by both enzymatic and non-enzymatic scavengers. SOD comprising a family of metalloenzymes occur in different isoforms as $\mathrm{Cu}-\mathrm{Zn} \mathrm{SOD}, \mathrm{Mn}$ SOD and Fe SOD, catalyse the dismutation reaction of $\mathrm{O}_{2}$ to $\mathrm{H}_{2} \mathrm{O}_{2}$ and $\mathrm{O}_{2}$ (Alscher et al., 2002) and is regarded as first line of defense against free radical mediated injury (Scandalio et al., 2001). The SOD activity increased maximum by $44 \%$ after $24 \mathrm{~h}$ of $1 \mathrm{mM} \mathrm{Cr}{ }^{+3}$ treatments. However, in response to $\mathrm{Cr}^{+6}$, a gradual decline at $10 \mathrm{mM} \mathrm{Cr}{ }^{+6}$ after $48 \mathrm{~h}$ treatment (Fig. 2A) was observed. These enzymes were located at different cellular sites, which had different resistances to the metals and the deterioration of cellular systems, affecting the SOD genes and resulting in their inactivation. (Mitller, 2002; Hou et al., 2007). CAT activities, on the other hand, decreased by $299 \%$ the shoot at $10 \mathrm{mM} \mathrm{Cr}^{+6}$ after $48 \mathrm{~h}$ treatment along with the increase in the concentration and duration of treatment (Fig. 2B). The gradual increase in the treatment in SOD activity had a simultaneous decline in CAT activity, with the increase in concentration and duration of treatment in Pistia, indicated strong accumulation of hydrogen peroxide (Srivastava et al, 2006). Perhaps, hydrogen peroxide acted as an oxidative stress, signal molecule under the condition of metal induced deactivation of $\mathrm{H}_{2} \mathrm{O}_{2}$, detoxifying enzymes, i.e., CAT that showed a gradual loss of stress protection in P.stratiotes L. The activity of GPx, on the other hand, was stimulated in response to $\mathrm{Cr}^{+6}$ after $48 \mathrm{~h}$ treatment in the root and shoot. Besides, it was observed that with the increase in $128 \%$ in the roots at $10 \mathrm{mM} \mathrm{Cr}^{+6}$ after 48h treatment (Fig. 2C), the GR activity initially remained unchanged with minor increase in the root and shoot after 24 and $48 \mathrm{~h}$ treatment. But the activity was stimulated by increasing in concentration due to significant increase in the root and shoots at $10 \mathrm{mM} \mathrm{Cr}^{+6}$ after $24 \mathrm{~h}$ treatment with respect to control. On the other hand, the GPx and GR activities increased by an hour of treatment in comparison to control that played an important role in preventing the oxidative stress (Weckx and Clijster, 1997; Panda and Upadhyay, 2008).

The observed changes for the generation of $\mathrm{H}_{2} \mathrm{O}_{2}$, lipid peroxidation, concentration of the nonenzymatic compounds and the activity of antioxidant enzymes could also be a result of chromium accumulating to distinct concentrations in the roots and shoots, resulting in different levels of oxidative stress as observed for other toxic metals (Vitória et al., 2001; Wahid and Ghani, 2008). The distribution of chromium within the plant system is a key factor to be considered and although was not analyzed such an aspect, chromium could be expected to have entered the plant system inducing the oxidative stress as measured by $\mathrm{H}_{2} \mathrm{O}_{2}$ and lipid peroxidation. The increase in GPx activity in treated plant was probably related to the oxidative reactions, corresponding an increase in peroxides and free radicals in the plant cells. The response of P.stratiotes L. with different concentrations of chromium could induce a concentration-dependent oxidative stress in the leaves as well as roots of $P$. stratiotes L, since it was found to be more sensitive to hexavalent chromium. The induction of antioxidative enzymes could be one of the processes, implicated in the regulation of chromium ion concentration in Pistia plant. The present results showed that, at the initial stages the $\mathrm{Cr}$ concentrations did not cause significant changes in the oxidative metabolism when measured by the induced enzymatic activity like that of GPx. Cr-concentration (1-10mM) caused more increase in the free radicals that induced the oxidative damage. These findings supported the concept that monitoring of the oxidative metabolism parameters in various plant species should be an integral part of evaluation as well as accumulation of the effect of metal stress in the plants. 


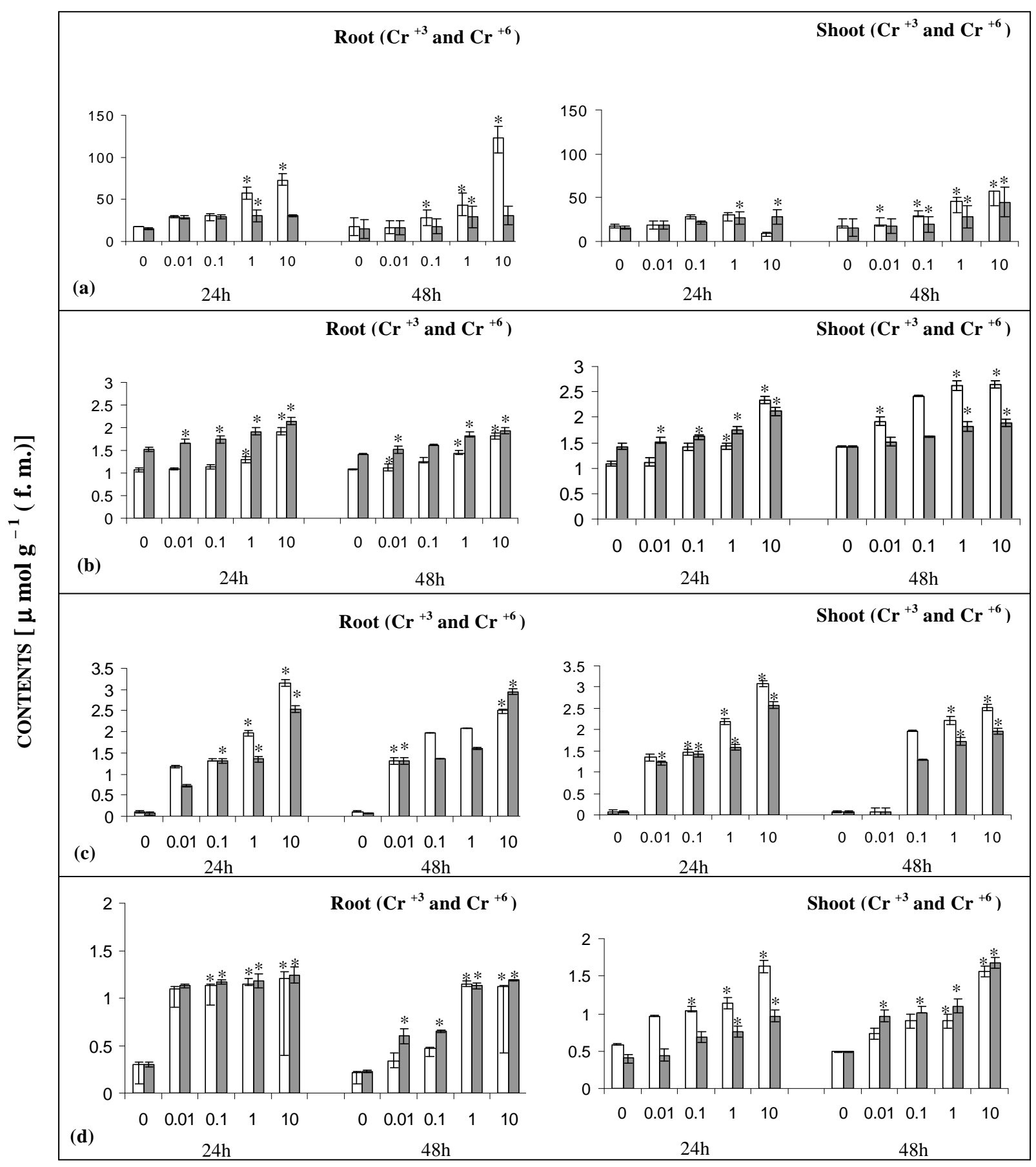

CONCENTRATION [ mM ]

Figure 1- Effects of $\mathrm{Cr}^{+3}(\square)$ and $\mathrm{Cr}^{+6}(\square)$ on $\mathrm{H}_{2} \mathrm{O}_{2}$ (a), MDA (b), ascorbate (AsA) (c) and glutathione (GSH+GSSG) (D) contents in roots and shoots of Pistia stratiotes L. The data presented are means of three replicates. * represents the significance level at $\mathrm{P}<0.005$ when compared with control. 


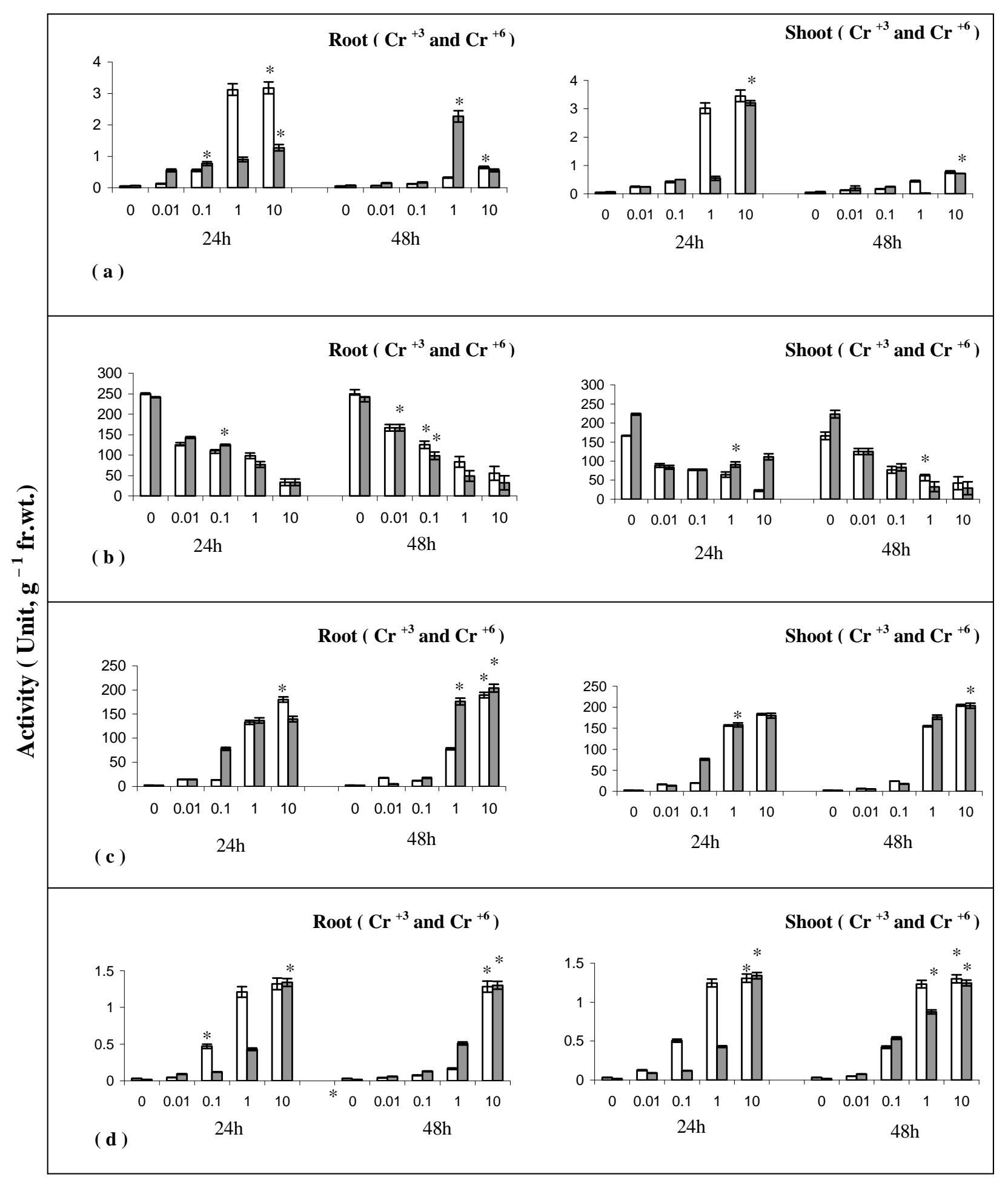

\section{Concentration ( $\mathrm{mM}$ )}

Figure 2 - Effects of $\mathrm{Cr}^{+3}(\square)$ and $\mathrm{Cr}^{+6}$ ( $\square$ ) on SOD (a), CAT (b), GPx (c) and GR (d) activities in roots and shoots of Pistia stratiotes $L$. The data presented are means of three replicates. * represents the significance level at $P<0.05$ when compared with control. 


\section{ACKNOWLEDGEMENT}

R. K. Upadhyay is grateful to the University Grant Commission (UGC), New Delhi, Government. of India, for the award of UGC Research Fellowship (Award No-AUK-204/12/2004/7816-66).

\section{REFERENCES}

Alscher, R.G., Erturk, N. and Heath, L.S. (2002), Role of superoxide dismutases (SODs) in controlling oxidative stress in plants. J. Exp. Bot., 53, 13311341.,

Arber, A. (1963), The life history of lemnaceae and Pistia, 73-83. In: water plants. Heninheim. JC Harper Publishing Co. New York.

Chance, B. and Maehly, A.C. (1955), Assay of Catalase and Peroxidase. Methods Enzymol., 2, 764 -775.

Culley, D.D., Jr Rejmankova, E., kvet, J. and Frye, J.B. (1981), Production, chemical quality and use of duckweeds (Lemnaceae) in aquiculture, waste management and animal feed. J. Wld Maricult Soc. , 12, 27- 49.

Dietz, K. J., Baier, M. and Kramer, U. (1999), Free redicals and reactive oxygen species as mediators of heavy metal toxic s ity in plants p, 73-79. In: Heavy metal stress in plants from molecules to ecosystems. Prasad MNV Hagemeyer J (Ed) Spinger-Verlag Berlin.

Fasulo, M.P., Bassi, M. and Donini, A. (1983), Cytotoxic effects of hexavalent chromium in Euglena gracillis. II. Physiological and ultrastructural studies. Protoplasma, 114, 35-43.

Gallego, S.M., Benavides, M.P. and Tomaro, M.L. (1996), Effect of heavy metal ion excess on sunflower leaves - evidence for involvement of oxidative stress. Plant Sci., 121, 151- 159.

Giannopolitis, C.N. and Ries, S.K. (1977), Superoxide dismutase I. Occurrence in higher plants. Plant Physiol., 59, 309 - 314.

Gratão, P.L., Polle, A., Lea, P.J. and Azevedo, R.A. (2005), Making the life of heavy metal-stressed plants a little easier. Funct. Plant Biol., 32, $481-494$.

Gratão, P.L., Monteiro, C.C., Antunes, A.M., Peres, L.E.P. and Azevedo, R.A. (2008), Acquired tolerance of tomato (Lycopersicon esculentum cv. Micro-Tom) plants to cadmium-induced stress. Annals Applied Biol., 153, 321 - 333.

Griffith, O.W. (1980), Determination of glutathione and glutathione disulphide using glutathione reductase and 2 - Vinyl pyridine. Anal Biochem., 106, 207 211.

Hou, W.; Chen, X.; Song, G.; Wang, Q. and Chang, C.C. (2007), Effects of copper and cadmium on heavy metal polluted water body restoration by duckweed (Lemna minor). Plant Physiol. Biochem., 45, 62-69.

Mittler, R. (2002), Oxidative stress, antioxidants and stress tolerance. Trends Plant Sci., 17, 405-410.

Oser, B.L. (1979), Hawks Physiological chemistry. Mc Graw Hill NewYork USA. pp, 702-705.

Paiva, L.B., de Oliveira, J.G., Azevedo, R.A., Ribeiro, D.R., da Silva, M.G. and Vitória, A.P. (2009), Ecophysiological responses of water hyacinth exposed to $\mathrm{Cr}^{3+}$ and $\mathrm{Cr}^{6+}$. Environ. Exp. Bot., 65, 403409.

Panda, S.K. and Choudhury, S. (2005), Chromium stress in plants. Braz. J. Plant Physiol., 17, 95-102.

Panda, S.K. and Upadhyay R.K. (2008), Biochemical changes and oxidative damage in Azolla pinnata $\mathrm{L}$. under chromium phytotoxicity stress. Indian J. Plant Physiol., 13, 243-250.

Prasad, K.V.S.K., Pardhasaradhi, P. and Sharmila, P. (1999), Concerted action of antioxidant enzyme and curtailed growth under zinc toxicity in Brassica juncea. Env Exp Bot., 42, 1- 10.

Razinger, J., Dermastia, M., Drinovec, L., Drobne, D., Zrimec, A. and Koce, J.D. (2007), Antioxidative responses of duckweed (Lemna minor L.) to shortterm copper exposure. Env. Sci. Pollut. Res., 14, 194201.

Sagisaka, S. (1976), The occurrence of peroxide in a perennial plants, Populus gelrica. Plant Physiol., 57, 308-309.

Scandalio, L.M., Dalurzo, H.C., Gomez, M., RomeroPuertas, M.C. and del Rio, L.A. (2001), Cadmium induced changes in growth and oxidative metabolism in pea plants. J. Exp. Bot., 52, 2115-2120.

Sinha, S., Saxena, R. and Singh, S. (2005), Chromium induced lipid peroxidation in the plants of Pistia stratiotes L., role of antioxidants and antioxidant enzymes. Chemosphere. , 58, 595-604.

Smith, 1.K., Vierheller, T.L. and Thorne, C.A. (1988), Assay of glutathione reductase in Crude tissue homogenates using $5,5^{\prime}$ - dithiobis (2-nitrobenzoic acid). Anal Biochem., 175, 408 - 413.

Srivastava, S., Mishra, S., Tripati, R.D., Dwivedi, S., Gupta, D.K. (2006), Copper induced oxidative stress and responses of antioxidants and phytochelitins in Hydrilla verticillata. Aquatic Toxicol., 80, 405-415.

Upadhyay, R.K. and Panda, S.K. (2004), Thermo sensitivity and regulation of activities of superoxide dismutase and guaiacol peroxidase by chromium ions in plants. Adv. Plant Sci, 17, 705- 708.

Upadhyay, R.K. and Panda, S. K. (2005), Biochemical changes in Azolla pinnata under Chromium toxicity. J. Plant Biol., 32, 49- 52.

Upadhyay, R. K. and Panda, S.K. (2009), Copperinduced growth inhibition, oxidative stress and ultrastructural alterations in freshly grown water lettuce (Pistia stratiotes L.). C. R. Biologies, 332, 623-632. 
Vitória, A. P., Lea, P. J. and Azevedo, R. A. (2001), Antioxidant enzymes responses to cadmium in radish tissues. Phytochem., 57, 701-710.

Vranova, E., Inze D. and Van Breusegem, F. (2002), Signal transduction during oxidative stress. J. Exp. Bot, 53, 1227- 1236.

Wahid, A. and Ghani, A. (2008), Varietal differences in mungbean (Vigna radiata) for growth, yield, toxicity; symptoms and cadmium accumulation. Annals Appl. Biol., 152, 59 - 69.

Weckx, J.E.J. and Clijsters, H.M.M. (1997), Zinc phytotoxicity inducing oxidative stress in primary leaves of Phaseolus vulgaris. Plant Physiol. Biochem., 35, 405- 410.
WHO. (1998), Chromium environmental health criteria. pp, $1-197$.

Zhang, X.Z. (1992), The measurement and mechanism of lipid peroxidation and SOD, POD and CAT activities in biological system. In: Zhang, X.Z. (ed) Research methodology of crop physiology. Agriculture Press, Beijing, pp 208-211.

Received: November 11, 2008; Revised: May 21, 2009; Accepted: April 17, 2010. 